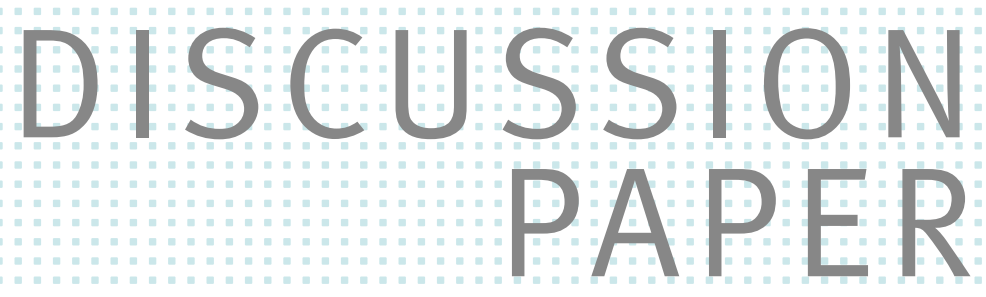

// ANNIKA HAVLIK, FRIEDRICH HEINEMANN, AND JUSTUS NOVER

\title{
Election Cycles in European Public Procurement
}




\title{
Election Cycles in European Public
}

\author{
Procurement
}

\author{
Annika Havlik $^{\dagger *}$ Friedrich Heinemann ${ }^{\dagger \dagger *}$ Justus Nover ${ }^{\dagger \S *}$ \\ †ZEW Mannheim ${ }^{\ddagger}$ University of Heidelberg ${ }^{\S}$ University of Mannheim
}

September 30, 2021

\begin{abstract}
This paper studies the existence of election cycles in public procurement in the European Union for the national level. We analyze different steps along the procurement process, namely the publication of the contract notice, the awarding of the contract, and the project completion. We point out how these steps should differ in their potential to address specific types of voters. We argue that the award provides politicians with a particularly appealing opportunity. It allows them to please the award-winning firms' stakeholders and the spending decision becomes binding and credible also from the perspective of forward-looking voters. We find robust evidence for electioneering in contract notices and awards prior to national parliamentary elections. The effect in contract awards is particularly strong for certain sub-categories like education and is more pronounced for visible projects.
\end{abstract}

JEL codes: D72, D73, H57

Keywords: Forward-looking voters, political budget cycles, retrospective voting, Tenders Electronic Daily (TED).

*We are grateful for helpful comments from Zareh Asatryan, Sebastian Blesse, Leonardo Giuffrida, Mustafa Yeter, participants at the EPCS Conference 2019 in Jerusalem and internal ZEW seminars as well as for valuable suggestions from three anonymous reviewers. Samuel Helbig and Cobi King have provided excellent research assistance. The authors gratefully acknowledge financial support from the Leibniz SAW project "Market Design by Public Authorities". Corresponding author: Friedrich Heinemann (friedrich.heinemann@zew.de). 


\section{Introduction}

An abundant literature has studied how politicians use various fiscal and economic policy instruments to improve their reelection prospect and how this may lead to political election cycles (for comprehensive surveys see Franzese (2002) and De Haan and Klomp (2013a)). Since the seminal papers of the 1970s (Hibbs 1977, Nordhaus 1975, Tufte 1978), rich and differentiated results have emerged. For the budgetary dimension, the empirical literature has shown that election cycles are easier to prove for targeted transfer programs with well-identified recipients than for budgetary aggregates. One reading of this result is that, due to various constraints (fiscal solvency, institutional restrictions of mature democracies, market pressure), the leeway for timing is limited for the fiscal aggregates, whereas politicians have more room of maneuver on the spending structure. Thus, politicians will tend to concentrate on those instruments that "deliver timed and clearly palpable and attributable (to in-

cumbents) economic benefits to large numbers of specific groups of voters" Franzese 2002 , p. 380).

Our contribution follows this guidance and looks at public procurement as one important type of a targeted fiscal instrument with its benefits for specific voter groups. Public procurement is the procedure where public authorities purchase work, products, and services from firms and it accounts for around 14\% of GDP in the European Union (European Commission 2020a). It belongs to the set of spending instruments that have an obvious potential to please certain groups of voters ahead of an election day in a highly salient way. A public contract does not only signal the provision of a public good or service but also identifies - as soon as it is awarded - a specific company and its workers who will provide it and earn income from the contract. A further interesting strategic feature is that a procurement award, due to its contractual nature, can be used as a commitment device for public spending beyond the next election. This makes it attractive for politicians 
confronted with forward-looking voters who are aware of politicians' incentives not to keep their pre-election promises. ${ }^{1}$

Given this obvious potential for electioneering, the procurement process is underresearched in the political budget cycle literature. To our knowledge, only two other papers exist that study political budget cycles (PBCs) in public procurement. Chong et al. (2014) find that public work contracts in French municipalities are more likely to end prior to legislative elections in case the mayor runs for reelection compared to municipalities where the mayor does not run for another term. Marx (2018) studies procurement cycles in the environment of developing economies with data of development projects funded by the World Bank in Sub-Saharan Africa. He finds that national incumbent governments are rewarded for the completion of visible projects prior to the election. Chong et al. (2014) concentrate on the timing with respect to the final delivery of the public contracts. Marx (2018) finds a more pronounced election cycle for the completion over the initiation of new projects and particular electioneering efforts for visible projects. Our study builds on these first studies but enriches it along important dimensions.

First, in our theoretical and empirical set-up, we take account of the full procurement cycle starting with the procurement call for tenders over the award decision up to the project completion (in the empirical part with somewhat weaker data for completions compared to calls and awards). The existing literature has not yet studied election patterns systematically along this full procurement cycle. We hypothesize that public procurement contracts should increase in size and number prior to each election but we differentiate this prediction with respect to each of these three stages. These differences emerge due to different types of beneficiaries and varying degrees of visibility and predictability along the procurement cycle, with

\footnotetext{
${ }^{1}$ With a partisan perspective, the binding nature of a procurement contract also offers a strategic tool to commit the succeeding government to spend on specific goods that are favored by the outgoing government Alesina and Tabellini 1990). In our contribution, we concentrate on the opportunistic motive in the election cycle literature that focuses on reelection motives.
} 
the timing of project completions particularly uncertain and difficult to control by politicians.

Second, we are the first to exploit the comprehensive project-level public procurement data from Tenders Electronic Daily (TED) to study the existence of election cycles in procurement for the Member States of the European Union (EU). Hence, whereas the two existing studies, with their focus on French municipalities (Chong et al. 2014) and World Bank projects in developing countries (Marx 2018), have a very specific institutional context, we provide empirical evidence on the procurement pattern for the national level throughout the EU.

We make full use of our project-level data to test also whether an election cycle is particularly manifest for specific types of contracts. For this purpose, we differentiate between the procurement of supplies, services, and public works; we look at different sectors; and we identify more "visible" projects in several ways (specific public functions, labor intensity, and project size).

For our empirical strategy, we employ panel fixed effects regressions and event study analyses with a Poisson pseudo-maximum-likelihood (PPML) estimator. We find evidence that the amounts and aggregate values of public procurement calls and, in particular, awards are higher prior to elections. The pronounced result for awards is in line with our theoretical reasoning that the award decision should have a particularly large electioneering potential also under the assumption of prospective voters who want to see a credible commitment on post-election spending. We find evidence for the role of visibility. Projects defined as visible in the literature are higher prior to an election. We do not find that projects are systematically larger or more labor-intensive prior to elections.

Our study is related to the cross-country studies that use disaggregated data for different spending categories to shed more light on the mechanisms behind political budget cycles. Enkelmann and Leibrecht (2013) conclude that budgetary cycles predominantly exist for new Eastern European democracies and particularly in the 
spending categories administration, environment, as well as economic and social expenditure. Bove et al. (2017) observe that OECD countries have higher social expenditures around elections at the expense of military spending. Vergne (2009) finds no effect for infrastructure spending in developing countries but rather an increase in wages and subsidies, while Schuknecht (2000) detects the existence of public investment cycles. These papers are just a small selection of existing papers analyzing different spending categories. De Haan and Klomp (2013b) provide an overview and explain differences in findings with heterogeneous level of development, institutional quality, level of democracy, and constitutional rules. Besides these cross-country studies, more recent papers often analyze local public goods in single countries $2^{2}$ Although these studies analyze specific spending categories they are still based on figures for realized public spending with data from annual budgets. Thus, they do not pay interest to the finer multi-stage process of realizing public expenditure through the procurement of goods and services as we do for our projectlevel public procurement data.

\section{Hypotheses, data, and empirical model}

\subsection{Theoretical considerations}

According to Tufte's conceptual approach (Tufte 1978), an election cycle in public policies can emerge if a "motive", an "opportunity", and an "instrument" are given on the side of the government. This logic has been fruitfully applied to understand possible cycles for spending, taxation but also other phenomena such as politicians' extra-parliamentary activities (Geys 2013). This triad also provides the basis to understand the electioneering potential for public procurement.

The standard motive in this literature is the incumbent's interest in reelection, which becomes more acute whenever in a democracy an electoral term draws to

\footnotetext{
${ }^{2}$ See Foremny et al. (2018) for an overview of sub-national studies on PBCs.
} 
its close. An opportunity on the eve of the next election exists if voting decisions depend to some extent on actions or signals from the incumbent in the pre-election period. As a rule, politicians should avoid negative signals (e.g., higher taxes) and provide positive signals (e.g., transfer increases) shortly before an election. An important issue in this regard that features prominently in the election cycle literature is the assumption on voters' expectation formation that can be assumed retrospective (Nordhaus 1975, Tufte 1978) or forward-looking (Rogoff 1990, Rogoff and Sibert 1988), or a combination of both. The models with forward-looking voters reconcile rational expectations with the existence of electoral cycles. The essential ingredient is that voters have incomplete information on politicians' types and politicians use their instruments in the election campaign to signal or feign advantageous characteristics (Franzese 2002). Finally, the incumbent needs an instrument under her control if she wants to exploit the existing opportunities for winning votes.

We look at the use of public procurement in EU democracies so that the standard motive - improving the reelection outlook - is given. We argue that the executive's use of public procurement is a potential instrument as procurement decisions send out very specific signals on the use of public money to voters. Crucially to our interest in the full procurement cycles, the opportunity for winning votes can vary over the different stages of the process. It is too simple to view a political "electioneering" of fiscal activities just as the optimal choice of one point in time. With respect to the public procurement process, this optimization entails a scrutiny of which phase in the process is politically most crucial. The reason is that voter target groups and the degree of spending commitment vary across these stages, as we will more carefully develop in the following.

Public procurement is a lengthy process with many steps involved until the project is finally delivered. There are different ways of initiating a project; either the government or administration itself decides to propose a project, or the project can be initiated by citizens via different forms of direct democracy. In both cases, a proposal 
has to be made to the responsible representative body who then decides whether the budget is approved. If this is the case, the call for tenders (also called contract notice) for a public procurement project is subsequently published and firms can submit their bids. The length of the period in which the firms can apply is defined in the call for tenders. After the submission deadline, the public procurement authority chooses the winning offer according to the criteria that were defined in the contract notice and the contract is awarded to one or several firms. Afterwards, the project phase starts, which can be very short, e.g., if the project is the purchase of simple consumption goods for a public authority, or very long, e.g., the construction of a new highway. Finally, once the project is completed there may be an opening ceremony, where politicians cut ribbons and declare the project finished or open. While the payment for supplies projects happens more or less simultaneously with project delivery, there will be several payments throughout the process for works or service projects that have a longer duration.

We concentrate on the three milestones within this process, which we also are able to observe in our database (at different degrees of data coverage with somewhat weaker coverage for completions): the contract notice, the project award, and the completion of the project. In the following, we develop how these stages differ with respect to their specific electioneering opportunities. For this purpose, we differentiate between the specific target groups that can be addressed and the degree of government commitment at each stage. The degree of commitment is essential for forward-looking voters who are aware that politicians might not keep their preelection spending promises.

Contract notice: The contract notice reveals in detail, what specific kind of public good or service the government intends to provide, or which supplies it plans to purchase for its own production of public services. The contract notice specifies the spending plans as they have already - on a more general level - been determined through the preceding budgetary decision. However, the notice is not yet a fully 
binding commitment. A tender might not come to a result or could be suspended. Moreover, the notice marks the start of a competition and does not yet identify the winning company that will provide the good or service. Hence, the contract notice's main electioneering opportunity originates from its information signal to voters who will benefit from the specified public good in future as users. Among those voters, this signal is less helpful for forward-looking, rational voters who are skeptical about political announcements that lack a fully binding commitment.

Project award: The instrumental potential for electioneering is different for the award decision that ends the procurement competition. First, compared to the contract notice, the award identifies additional, more specific voter groups who will particularly benefit. These include stakeholders of the company from management to workers up to all those who take advantage from positive spillovers that arise from a prospering company. These spillovers from the award-winning local company benefit such groups as suppliers to this firm but also the tax-receiving local jurisdiction and its citizens. Second, with the contract awarded, the dates for the project start and the planned completion are set which gives a more reliable indicator on the availability of the new public good. Third, due to the legal commitment of the awarded contract, this is a highly credible signal on future public spending and the provision of a public good. With the legal standards of the EU, a public contract constitutes a binding spending commitment from the government $]^{3}$ In this sense, the award decision indicates the point of no return for the spending plan and constitutes a credible election promise. This should appeal to voter types that are fully forwardlooking and understand the incentives of incumbents to break pre-election promises. Since both the credibility of the spending promise increases and the award reveals additional groups of beneficiaries, there are substantial theoretical arguments to expect a conscious timing of awards for electioneering purposes in particular.

\footnotetext{
${ }^{3}$ With the possibly weaker legal institutions of a developing country, this may not be the case so that only a start of the project or the project completion is the fully credible signal in this context (Marx 2018).
} 
Project completion: Finally, the project completion with its "red ribbon" moment (Chong et al. 2014) of the opening ceremony is arguably a particularly visible moment in the procurement process. However, at least for well-informed voters, the opening as such does not provide substantial new information. The public good has already precisely been defined in earlier stages of the procurement process. Moreover, a continuous involvement of citizens throughout the planning and construction stage has become the rule rather than the exception. Another argument against the usefulness of the project completions for electioneering is the particular difficulty of a precise timing ex ante. At least the larger construction projects are lengthy and confronted with substantial operational uncertainties entailing frequent delays. Therefore, contrary to project notices or awards, it appears infeasible to manipulate the timing of completions with the precision landing needed to reach an impact in the few crucial months or even weeks of an election campaign.

Apart from the differentiation between the three stages of the procurement process, we conjecture that different types of procurement contracts are not identical in their political usefulness before an election. Following the literature and based on own reasoning, we see the following approaches to differentiate the universe of contracts:

Services, works, or supplies: A public authority may procure supplies to provide its own services (e.g., IT equipment), it may contract out service provision (e.g., maintenance), or it may procure investment projects that entail substantial public works (e.g., street construction). These types of procurement differ with respect to their length, predictability, employment effect, location of value creation, and salience. Chong et al. (2014) argue that contracts on public works should have a particular potential for electioneering.

Sectoral differences: Moreover, there could be heterogeneous effects according to the sector of the procurement contract. There is no universal result on which expenditure categories dominate prior to elections. De Haan and Klomp (2013b) provide an overview of papers studying different spending categories and discuss possible 
determining factors for the heterogeneous findings. Hence, we approach the sectoral classification (making use of the International Standard Industrial Classification, ISIC) without clear predictions.

Visibility proxies: To zoom in on the visibility dimension of public procurement, we see three avenues. First, we can identify visible projects as already done in the literature. Chong et al. (2014) classify visible projects in the context of France as streets and public buildings such as sport, recreational, or social buildings and schools. Marx (2018) classifies visible projects as being in the transportation, electricity, water, education, and health sector. Second, we can classify projects according to the labor intensity of the corresponding sector. Higher labor intensity means that the project needs a higher labor force on average and this labor force consists of potential voters. Third, visibility can be a function of project size. Hence, we can test whether larger projects increase in number and value before elections.

Summing up, our reasoning backs the following theoretical expectations that we test through our empirical design. We see arguments to expect an election cycle for public procurement, which should be most pronounced for notices and awards. The use of awards prior to an election should have special appeal to policy-makers if they want to target award-winning firms together with their stakeholders and if they are confronted with forward-looking voters who need binding spending commitments. Moreover, we do not expect the election cycle to be equally strong across all types of procurement contracts. Cyclical patterns should be more noticeable for visible projects, public works, and might differ across sectors. We now turn to the description of our project data and their potential to test our hypotheses.

\subsection{Data}

Public procurement data: The data on public procurement contracts is taken from Tenders Electronic Daily (TED), a platform provided by the European Commission that stores all public procurement notices and awards with contract values exceeding 
a certain threshold. The thresholds vary across contract types as outlined in the EU Public Procurement Directives 2014/23/EC and 2014/24/EC. The lowest threshold for certain types of services is 139,000 euros. ${ }^{4}$ Countries can (and sometimes do) voluntarily publish contracts below the thresholds. In our analysis, we include all contracts listed on TED, irrespective of their size. We use information on the contracting authority, the number of projects, details on the procured goods like the main activity and sector, and the value of projects.

While the platform tries to harmonize public procurement information across Europe, there is still some heterogeneity across countries as some of them only publish the information that is obligatory, while other countries voluntarily also publish contracts with values below the official thresholds $5^{5}$ In addition to this, it is possible that politicians increase the number of contracts below the thresholds or even split larger projects into several smaller ones before elections to speed up the procedure without having to comply with the rules that are in place for contracts above the thresholds. Evidence for such a behavior by politicians is found in Castellani et al. (2018) for Italy. For our analysis, this would imply that we rather underestimate the true election cycle effect in the number of contracts when looking at the TED data as we miss out on some of the smaller contracts. The implications for the election cycle in the volume of projects is less clear. If an increase in the number of small projects before elections is budget neutral or increases the overall volume (i.e., larger projects are split into smaller ones without decreasing the total volume), we would also underestimate the true effect. If, however, a split of projects decreases the overall volume, then we would overestimate the true effect.

As we study national elections, we only include public procurement contracts from national authorities. We concentrate on the categories "Ministry or any other na-

\footnotetext{
${ }^{4}$ More information on the thresholds can be taken from European Commission (2020b) or from the mentioned Directives.

${ }^{5}$ According to an estimation by Skuhrovec (2017), Germany publishes less than $10 \%$ of its total public procurement volume, whereas Latvia publishes more than $50 \%$.
} 
tional or federal authority" and "National or federal agency / office" from Table 1. which are clearly identifiable as being governed by a national government ${ }^{6}$

Table 1: Authorities in TED

\begin{tabular}{|c|c|c|c|c|c|c|}
\hline \multirow[b]{2}{*}{ Authority } & \multicolumn{2}{|c|}{ Notices } & \multicolumn{2}{|c|}{ Awards } & \multicolumn{2}{|c|}{ Completions } \\
\hline & Freq. & Percent & Freq. & Percent & Freq. & Percent \\
\hline National or federal ministry / authority & 191,993 & 10.09 & 190,563 & 10.87 & 29,208 & 9.49 \\
\hline Regional or local authority & 583,227 & 30.66 & 517,039 & 29.49 & 110,772 & 35.98 \\
\hline Water, energy, transport and telecommunications & 183,000 & 9.62 & 156,455 & 8.92 & 27,482 & 8.93 \\
\hline European Union institution / agency & 10,380 & 0.55 & 10,533 & 0.60 & 175 & 0.06 \\
\hline Other international organization & 879 & 0.05 & 602 & 0.03 & 87 & 0.03 \\
\hline Body governed by public law & 408,100 & 21.45 & 390,517 & 22.27 & 54,482 & 17.70 \\
\hline Other & 401,024 & 21.08 & 345,539 & 19.71 & 67,609 & 21.96 \\
\hline National or federal agency / office & 31,862 & 1.67 & 30,766 & 1.75 & 4,620 & 1.50 \\
\hline Regional or local agency / office & 52,940 & 2.78 & 47,997 & 2.74 & 10,091 & 3.28 \\
\hline Not specified & 38,941 & 2.05 & 63,309 & 3.61 & 3,343 & 1.09 \\
\hline Total & $1,902,346$ & 100 & $1,753,320$ & 100.00 & 307,869 & 100.00 \\
\hline
\end{tabular}

Source: own calculations based on TED data.

Figure 1 plots the number and aggregate value of national contracts both by country and by year.7 The number of contracts by year (sub-figure a) is quite stable over time, with slightly higher levels in 2017 and 2018 for contract notices and awards. The number of contract completions is only a small fraction of the awards as only few observations in the data have the completion date indicated. The number of contract notices and awards are quite similar 8

Election data: The data on national elections is taken from the Voter Turnout Database by the International Institute for Democracy and Electoral Assistance (International IDEA) and contains information on the election year, whether the national parliament or the national president was elected, and the turnout rate. The exact election months were collected by hand. Our sample covers 81 parliamentary elections and 30 presidential elections in the European Union.

\footnotetext{
${ }^{6}$ Unfortunately, there are some categories which are not clearly identifiable in TED as national or sub-national. These are the categories "Body governed by public law", "Other", and "Not specified". We do not include observations from these categories in our analysis.

${ }^{7}$ Throughout the analysis, we exclude projects in the 1st and 99th percentile to avoid that extreme outliers affect the results.

${ }^{8}$ Reasons for deviations between the two are: notices that are canceled before leading to a contract award, the notice and the award taking place in different years, notices being split up into several awards, several notices being combined into one award, or awards without prior notices.
} 
Figure 1: Summary statistics for public procurement contracts

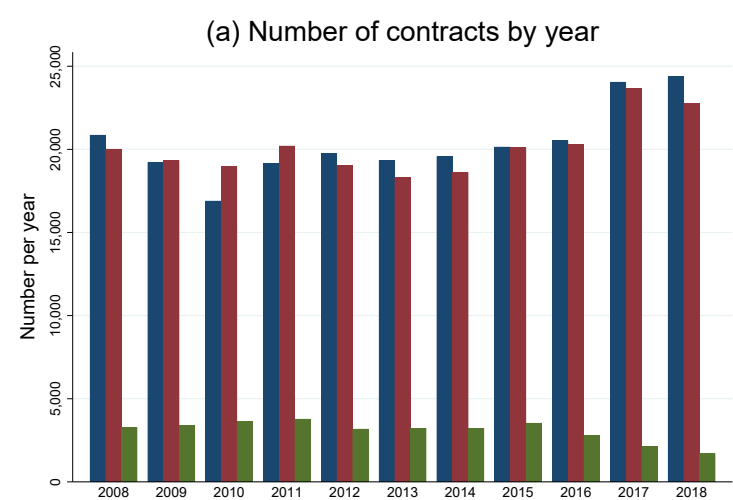

(c) Number of contracts by country

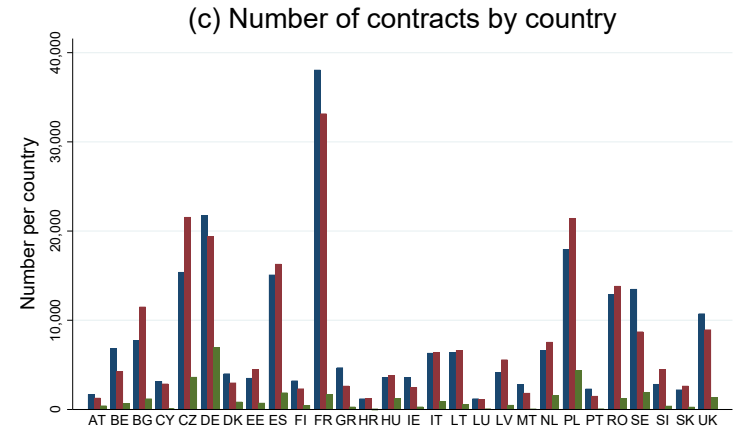

(b) Aggregate value of contracts by year

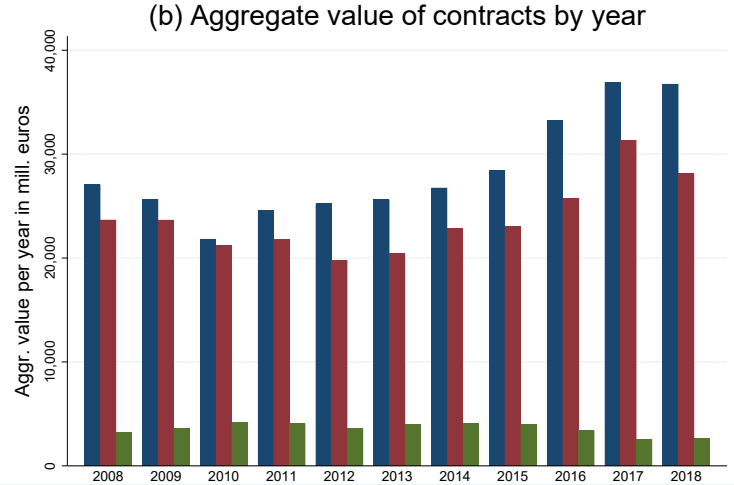

(d) Aggregate value of contracts by country

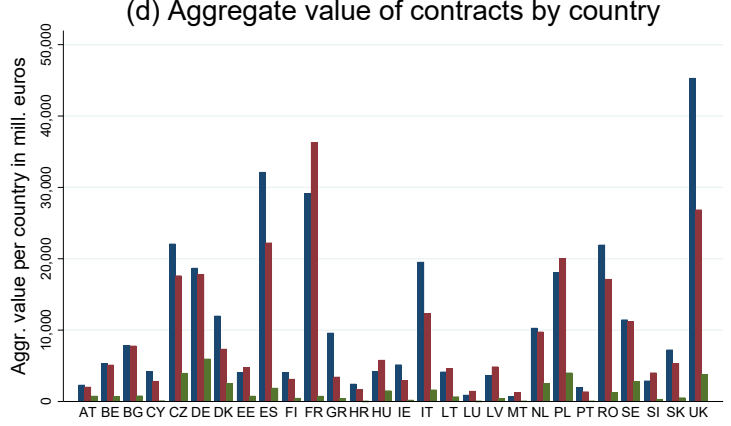

notices

awards

completions

Notes: The figures plot the amount and aggregate value of contracts by year and country for contract notices, awards, and completions. Only national contracts from the categories "Ministry or any other national or federal authority" and "National or federal agency / office" are included. Source: own calculations based on TED data.

Control variables: We include economic and demographic variables from Eurostat to control for time-varying country-specific characteristics. These are the GDP growth rate, government expenditure as a share of GDP, unemployment rate, population size, and the shares of the population aged younger than 15 and older than 64. Public procurement can serve as a tool for anti-cyclical spending, hence we might expect a negative effect of the GDP growth rate on public procurement. Moreover, we include a variable capturing the ideology of the government as this is often correlated with public expenditure.9 Summary statistics for these variables are provided in Table A1 in the Appendix.

\footnotetext{
${ }^{9}$ We use the seat share of left-wing parties in parliament from the "Comparative Political Data Set". The exact definition of this variable is: "Government composition: relative power position of social democratic and other left parties in government based on their seat share in parliament, measured in percentage of the total parliamentary seat share of all governing parties. Weighted by the number of days in office in a given year" (Armingeon et al. 2020).
} 


\subsection{Empirical model}

For the empirical analysis, we aggregate the public procurement data to the monthly level by country. The main analysis uses a Poisson pseudo-maximum-likelihood (PPML) model by Santos Silva and Tenreyro (2006). They show that with heteroskedastic data, log-linearized estimation equations, and count data, the PPML estimator is less biased than OLS. The authors also show that their estimator is a good way to deal with zeros in the dependent variable. The method is frequently used for trade data (Santos Silva and Tenreyro 2006), but also has applications in estimating effects on merger and acquisition deals (Todtenhaupt et al. 2020). Public procurement data is essentially count data. Moreover, when analyzing specific product categories, the dependent variable will contain a non-negligible amount of zeros such that the PPML estimator is the appropriate method for this study. We estimate the following model:

$$
\begin{array}{r}
Y_{i m t}=\exp \left(x_{i m t}^{\prime} \beta\right) \text { with } \\
x_{i m t}^{\prime} \beta=\alpha_{1}+\gamma \cdot \text { election_year }_{i m t}+\delta \cdot \mathbf{X}_{\mathbf{i t}}+\psi_{i}+\mu_{m t}+\varepsilon_{i m t},
\end{array}
$$

where $Y_{i m t}$ is the outcome variable of country $i$ in month $m$ in year $t$. It captures the total number or value of contract notices, awards, or completions. TED data is available from 2006 to 2018, whereas Eurostat only provides data on country-level background characteristics for 2008 to 2018 such that we focus on these eleven years in our analysis.

The variable election_year is a dummy capturing the twelve months leading up to an election with the last month being the election month. This "election year" definition is different from the one employed in many other papers from the PBC literature, where the election year corresponds to the calendar year in which an election takes place. There is no alternative available for these papers if they only have yearly data at hand. Our definition has the advantage that it is more precise 
as the calendar definition lumps elections in January together with elections in December, which most likely distorts the pre-election effect.

Matrix X captures demographic and economic controls as described above. Finally, $\psi_{i}$ are country fixed effects and $\mu_{m t}$ are month $\times$ year fixed effects to control for seasonal trends. The error term is clustered at the country level.

In order to better understand the dynamics of public procurement around elections, we also use an event study approach and estimate the effects for each month. We continue to rely on PPML models for these estimations. Following Fuest et al. (2018), the equation for the event study reads as follows:

$$
Y_{i m t}=\exp \left(\alpha_{1}+\sum_{k=-24}^{+12}\left(\gamma_{k} \cdot \text { election }_{i(m t+k)}\right)+\delta \cdot \mathbf{X}_{\mathbf{i t}}+\psi_{i}+\mu_{m t}+\epsilon_{i m t}\right) .
$$

The coefficient of interest is $\gamma_{k}$, i.e., the effect of an election. We include 24 leads and 12 lags to capture the evolution of two years before and one year after the election. The event dummies are binned at the window ends -24 and +12 to account for all elections outside the effect window (see, e.g., Fuest et al. 2018, Schmidheiny and Siegloch 2019). As an example, the variable election $_{i(m t+12)}$ is therefore equal to 1 if an election took place 12 months before this date or more months ago. Finally, and somewhat different to standard practice, we exclude and normalize to zero L1 (the month after the election) instead of F1 (the month before the election), because we are primarily interested in the dynamics before the election. This has no impact on inferences but simply determines a baseline that we think is most useful for our analysis of election cycle effects.

A possible endogeneity concern in both regression models is that the timing of an election might be endogenous. Due to political scandals or low performance, the incumbent might decide to resign and to call early elections. If low political performance negatively impacts on the economy this is likely to also affect public procurement. The included control variables can only partly account for this endogeneity. As a robustness check, we therefore include country $\times$ year fixed effects 
instead of the controls to address such endogeneity concerns. In addition to this, we also estimate models where we exclude all elections that took place prematurely.

\section{Results}

\subsection{Baseline models}

Table 2 shows the baseline results that addresses our key hypothesis that public procurement should show a peak prior to an election. In line with our interest into the full procurement cycle, we separately analyze contract notices (columns 1-4), contract awards (columns 5-8), and project completions (columns 9-12), looking both at the number of projects and their total value (both aggregated to the countrylevel). Moreover, we separately look at parliamentary and presidential elections as the literature identifies different effects for these regimes with yet no final conclusion on which regime exhibits larger election cycles (see, e.g., De Haan and Klomp 2013a, for a discussion). We use both project values and the number of contracts as dependent variables since politicians may have an incentive to split the procurement budget into smaller projects prior to an election in order to please a larger number of award-winning firms and their employees (we come back to a more specific test of project size in Section 3.2.

For contract notices, we find positive and statistically significant effects for both the number of contracts and their aggregate value when looking at years with a parliamentary election. These results suggest that in the considered election years, there are on average $8 \%$ more contract notices than in the other months that are not shortly before an election. This higher number of contract notices is accompanied by a $13 \%$ higher aggregate value of contract notices in the election year ${ }^{10}$ Similar effects are found for contract awards around parliamentary elections, for which both the number and aggregate value is about $13 \%$ higher than in non-election years.

\footnotetext{
${ }^{10}$ To interpret the coefficients, one has to apply the transformation (exp(coefficient)- 1$) * 100$.
} 
Finally, for project completions, the coefficients for parliamentary election years are also positive but statistically insignificant at conventional levels ${ }^{11}$

Turning to the models that study presidential election years, we find no statistically significant effects for any of the considered outcome variables ${ }^{12}$ As within the EU, only France and Lithuania exhibit a semi-presidential regime, for this category we also include presidential elections from countries with a parliamentary system in which the president is directly elected by citizens but lacks executive power (e.g., Austria). Taking this into account, the non-finding for presidential elections is not too surprising for the sample of EU member states in which parliamentary elections decide on the executive authority. We therefore continue the analysis by focusing on parliamentary elections only.

The presented evidence speaks for an election cycle in contract notices and awards for parliamentary elections. There is only little evidence for an effect on contract completions. This latter non-finding is in line with our theoretical reasoning that the finalization of a project is difficult to predict precisely for the incumbent. From this perspective, it might seem logical that electioneering rather occurs with contract notices and awards. However, the non-significant effects for project completions could also be due to the small number of observations, for which we know the completion date. To test this possibility, we also run regressions on the quarterly level to mitigate the effect of having only few contract completions each month.

Table A2 in the Appendix shows how the switch from a monthly to a quarterly aggregation has very little impact on the coefficient estimates for contract notices and awards such that our conclusions for these outcome variables are robust to this adjustment. In contrast, for contract completions, we now also see more precisely estimated effects, suggesting that the number (value) of contract completions is higher by $6 \%(16 \%)$ in the 12 months preceding an election. Statistical precision is,

\footnotetext{
${ }^{11}$ Appendix Figure A1 descriptively documents the evolution of the number and value of contract notices, awards, and completions. These figures largely support the above-drawn conclusions.

${ }^{12} \mathrm{We}$ also run regressions that jointly look at parliamentary and presidential elections. The results are very similar to those for parliamentary elections only and are available upon request.
} 
Table 2: Baseline regression results

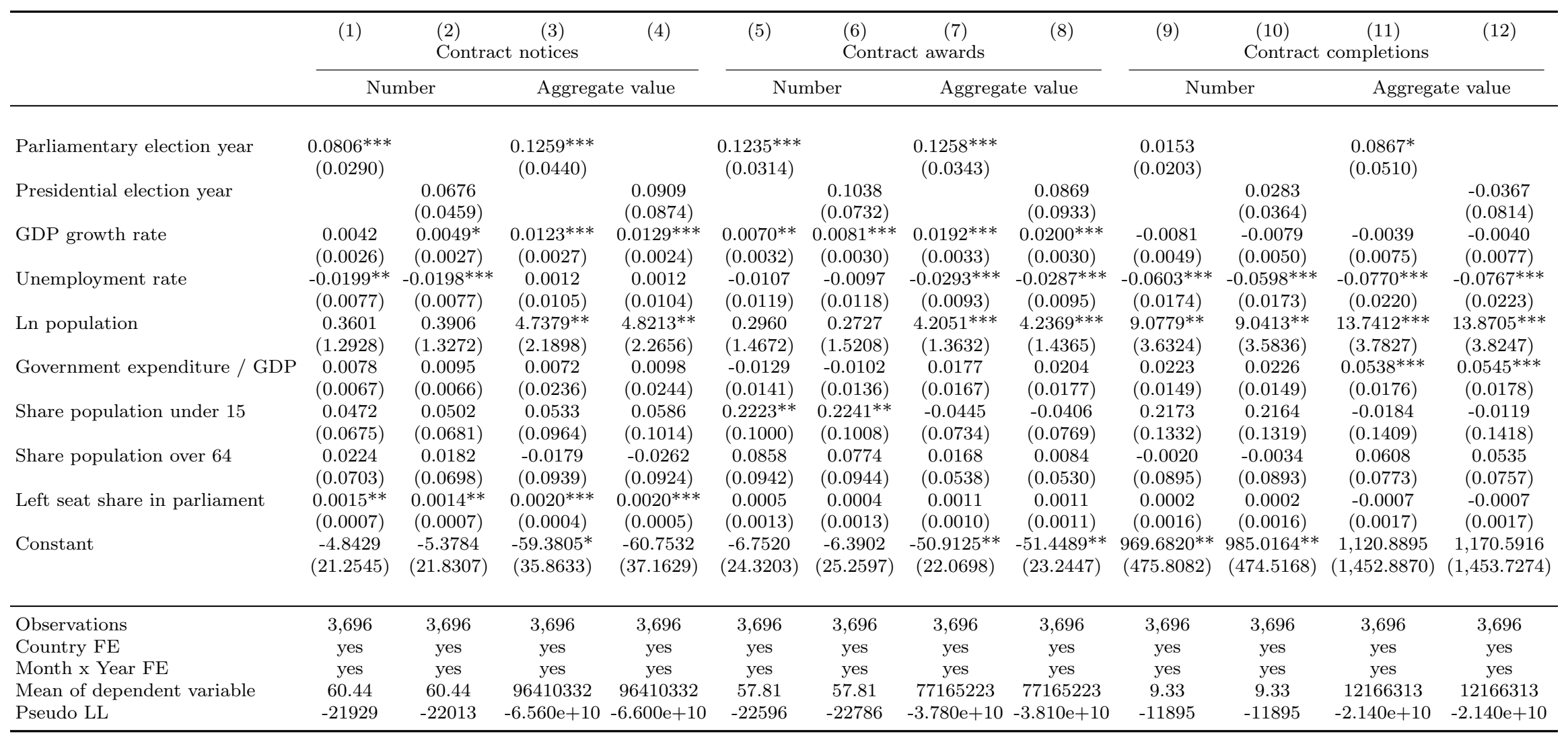

Notes: PPML regressions. ${ }^{* * *} \mathrm{p}<0.01,{ }^{* *} \mathrm{p}<0.05,{ }^{*} \mathrm{p}<0.1$. Results correspond to Equation $(1)$. Standard errors clustered at the country level. 
however, still lower than in the other regressions. For completeness, we nevertheless discuss these project completion results but abstain from looking at any heterogeneities in the effects in the subsequent section 13

Next, we concentrate on the dynamics of public procurement around parliamentary elections. First, we look at changes in public procurement over the period of one year but for different years in the election cycle. More precisely, we study the dynamics in procurement projects for the period two years before an election until one year after an election. Table A3 in the Appendix presents results. For contract notices (Panel A), we only find positive and statistically significant effects in the 12 months preceding an election (for both the number and value of contract notices), whereas in the year after an election, the value of contract notices is statistically significantly lower than in the other years. For contract awards (Panel B), we see a build-up of the election cycle as there are already some smaller positive changes in contract awards in the pre-election year that lead to larger and precisely estimated effects in the election year itself. Similar to contract notices, contract awards are lower in the post-election year. These effects are found for both the number and the value of contract awards.

Overall, the absence of large robust effects in the months two and three years before an election, combined with the slow build-up of the positive changes in public procurement 1-2 years before an election, support the interpretation that the identified effects are driven by an active manipulation of procurement contracts by politicians rather than the interpretation of a natural cycle that is due to a longer government formation process. If the effects would be due to newly formed governments taking

\footnotetext{
${ }^{13}$ To further test the robustness of the effects, we perform two additional checks (results available upon request). First, we use the "score bootstrap" method by Kline and Santos (2012) to address the potential problem of having only few clusters when adjusting the standard errors. The results consistently speak for an election cycle in contract notices and awards before parliamentary elections. Second, we re-estimate the baseline models but (i) use OLS regressions instead of the PPML method, (ii) exclude 26 "snap elections" that took place prematurely, and (iii) include country $\times$ year fixed effects to address potential endogeneity concerns with early elections. In the OLS model, the election effects on the number of contract notices and awards are somewhat smaller but robust. The effects on contract values are no longer statistically significant. The exclusion of snap elections and the inclusion of country $\times$ year fixed effects have only little impact on the results.
} 
Figure 2: Event study analysis

(a) Number of contract notices

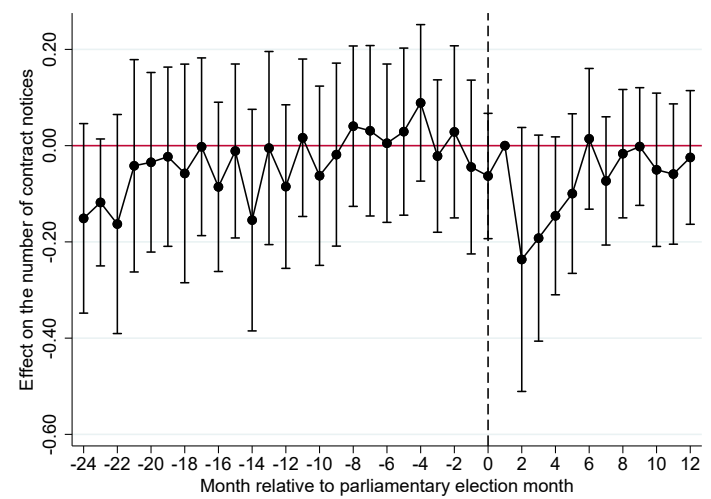

(c) Number of contract awards

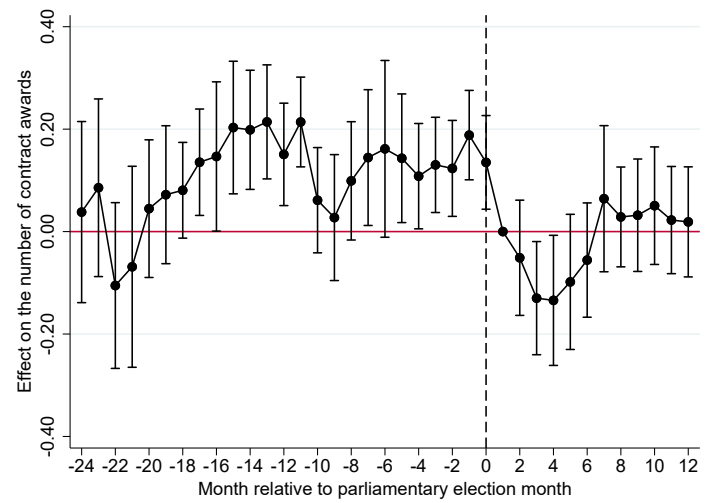

(b) Aggregate value of contract notices

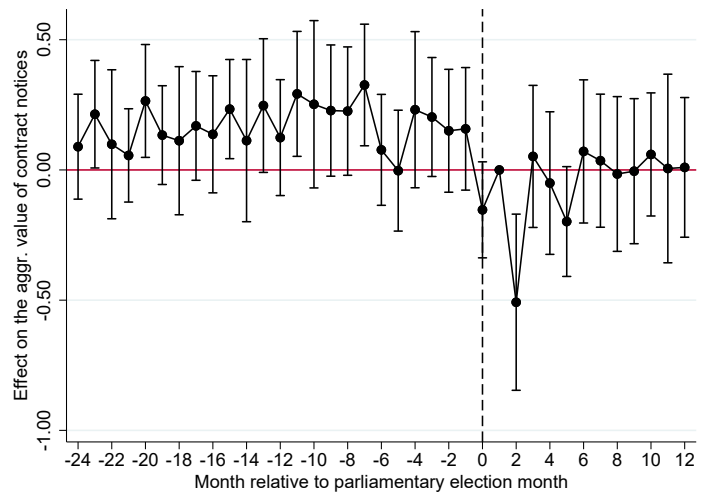

(d) Aggregate value of contract awards

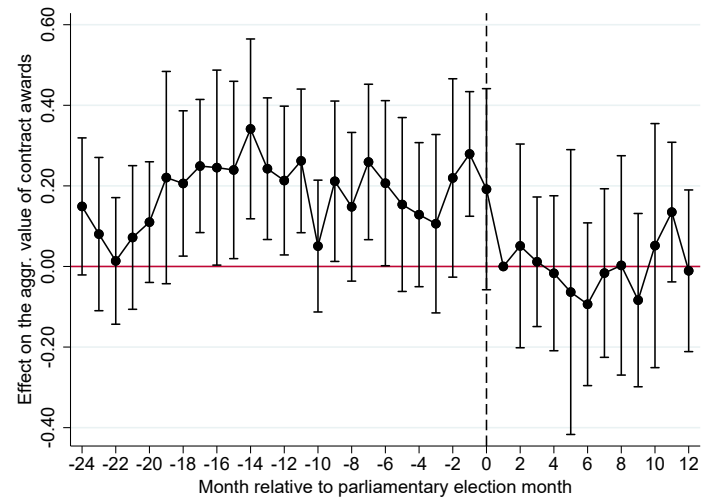

Notes: Coefficient estimates and 95\% confidence intervals for the event study model in Equation (2). PPML regressions. Standard errors clustered at the country level.

some time before being able to re-start the public procurement process, then we should see very similar effects in the $2-3$ years before an election and then only a drop in procurement projects in the months after an election.

In a second approach to study the dynamics in public procurement, we use event study analyses as specified in Equation (2). Figure 2 shows the results. For the number of contract notices (sub-figure a), we observe a slight increase before an election, followed by a drop in contract notices in the five months after an election but the coefficient estimates are not statistically significant. For the aggregate value of contract notices (sub-figure b), there are a few statistically significant and positive effects in the pre-election period. In line with expectations, the level of point estimates is higher in the pre-election period than in the post-election period. Turning 
to the contract awards, the number of awards (sub-figure c) shows strong positive deviations that are mostly statistically significant at the 5\% level from about 15 months prior to an election. Shortly after an election, coefficient estimates become negative and only return to the zero-level approximately seven months later. For the aggregate value of contract awards (sub-figure d), statistical precision is somewhat lower but the results convey a similar picture as for the number of awards. These observations are consistent with the findings of the analysis for different years of the election cycle in Table A3 ${ }^{14}{ }^{15}$

In the next step, we test for our second type of hypotheses that political usefulness prior to an election should also depend on the type of procurement project, e.g. with respect to differences in salience or employment effects. For this analytical step, we zoom in on project awards for which we have a particularly strong theoretical case that an electioneering potential exists and for which the preceding empirical results have confirmed a robust election link for their aggregates.

\subsection{Heterogeneities in election cycle effects}

In this section, we analyze heterogeneities in election cycles for contract awards along the three classifications introduced in Section 2.1: first, services versus works and supplies; second, sectors; and third, classifications according to various visibility proxies including labor intensity and product size.

First, Table 3 separately looks at country aggregates for contracts in the categories services, supplies, and works. For the number of contract awards, the largest point estimate is identified for services with an associated effect of $15 \%$. For supplies and works, we identify an election-year effect of around $11 \%$, even though for the

\footnotetext{
${ }^{14}$ Figure A2 in the Appendix shows the event study graphs using linear estimation models instead of the PPML estimator. The effects are estimated with less statistical precision but the overall trends in public procurement projects are the same.

${ }^{15}$ For presidential elections, we do not find evidence for an election cycle in our baseline models. To rule out that this non-finding is driven by the possibility of election effects occurring earlier in presidential elections than in parliamentary elections, we also estimate event studies for these events. Results are available upon request and consistently speak against an election cycle surrounding presidential elections.
} 
Table 3: Election effects by type of contract award

\begin{tabular}{|c|c|c|c|c|c|c|}
\hline & (1) & $(2)$ & (3) & $(4)$ & (5) & (6) \\
\hline & \multicolumn{3}{|c|}{ Number of contract awards } & \multicolumn{3}{|c|}{ Aggregate value of contract awards } \\
\hline & Services & Supplies & Works & Services & Supplies & Works \\
\hline Election year & $\begin{array}{c}0.1403^{* * *} \\
(0.0368)\end{array}$ & $\begin{array}{c}0.1047^{* * *} \\
(0.0290)\end{array}$ & $\begin{array}{c}0.1014^{*} \\
(0.0573)\end{array}$ & $\begin{array}{c}0.1552^{* * *} \\
(0.0396)\end{array}$ & $\begin{array}{l}0.0807^{*} \\
(0.0476)\end{array}$ & $\begin{array}{c}0.2205^{* * *} \\
(0.0693)\end{array}$ \\
\hline Observations & 3,696 & 3,696 & 3,696 & 3,696 & 3,696 & 3,696 \\
\hline Country FE & yes & yes & yes & yes & yes & yes \\
\hline Month $\times$ year FE & yes & yes & yes & yes & yes & yes \\
\hline Mean dep. variable & 30.59 & 22.79 & 4.63 & 30373251 & 22386944 & 29737493 \\
\hline Pseudo LL & -16109 & -16457 & -7993 & $-2.140 \mathrm{e}+10$ & $-1.840 \mathrm{e}+10$ & $-5.820 \mathrm{e}+10$ \\
\hline
\end{tabular}

Notes: PPML regressions. ${ }^{* * *} \mathrm{p}<0.01,{ }^{* *} \mathrm{p}<0.05,{ }^{*} \mathrm{p}<0.1$. Results correspond to Equation (1). The dependent variable only captures country aggregates for the respective category of contract awards: services, supplies, or works. Standard errors clustered at the country level.

works category, this effect is only statistically significant at the $10 \%$ level. For the aggregate value of contract awards, the largest point estimate is found for the works category. The aggregate value of works contracts is on average $25 \%$ higher in parliamentary election years than in other years. For services and supplies, this effect is roughly $17 \%$ and $8 \%$, respectively. In summary, there is no clear dominance of one category, although the most robust effects are found for services.

Second, Figure 3 presents the results for contract awards by ISIC sector codes ${ }^{16}$ The largest and statistically significant point estimate is found for the sector "Other services, activities of extraterritorial bodies" with an effect of 39\%. This category includes services like car park management, port management, accommodation management, janitorial services, and many more. According to Table A4, it captures fewer contracts than other categories. Similarly large effects are identified for "Education", "Financial and insurance activities", and "Accommodation and food service activities". Figure A3 in the Appendix collects the results for the value of contract

\footnotetext{
${ }^{16}$ Appendix Table A4 shows summary statistics by sector according to the section in the International Standard Industrial Classification of All Economic Activities (ISIC) Revision 4. The matching between procurement contracts and ISIC sections was done manually based on the Common Procurement Vocabulary (CPV) 2008 version indicated for each contract in TED. Note that some observations in the TED data still contain the CPV 2003 version. This was updated manually. The first two digits of the CPV correspond to the product division that can be easily matched to the ISIC section. Appendix Table A5 documents the matching of CPV and ISIC codes.
} 
Figure 3: Election effects on the number of contract awards by ISIC sector codes

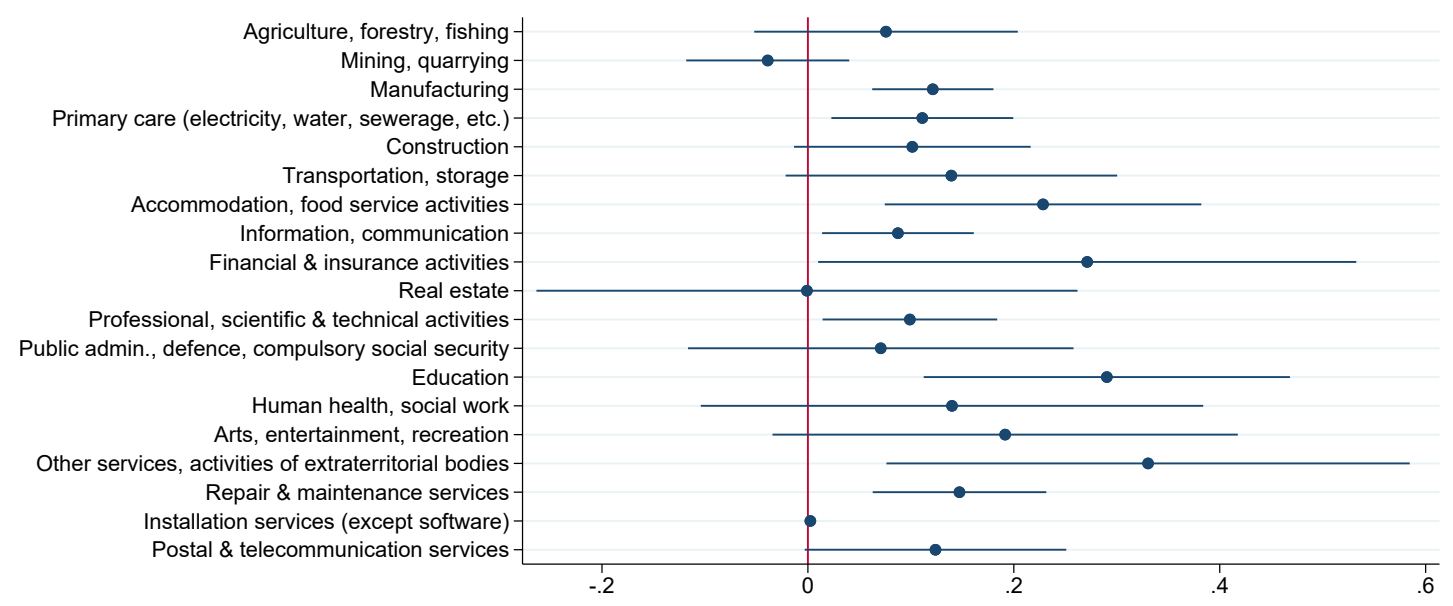

Notes: Coefficient estimates and 95\% confidence intervals for the parliamentary election year dummy. Separate regressions. The dependent variable only captures country aggregates for the respective category of contract awards as defined by the labels and summarized in more detail in Table A4 Results correspond to Equation (1). Standard errors clustered at the country level.

awards by sector. The education sector exhibits the largest effect, followed by the agricultural and the construction sector. As the construction sector has a very high aggregate value but only accounts for a relatively small number of contract awards, it is logical that the effect is only present for the value of contract awards but not for the total number.

In sum, the baseline effects seem to be driven by more than just a few sectors, although these are not the same when looking at the number of contract awards and their aggregate value. An exception in this regard is the education sector which exhibits statistically significant and large effects for both the number and value of contract awards.

Next, we try to better understand the underlying mechanisms behind the identified election cycles in public procurement. If incumbents aim to increase voter attention for public good provision by initiating new projects, then they should put more emphasis on particularly visible projects. To test whether this is the case, we use three different definitions of visible projects: First, projects are classified into visible and non-visible following standard approaches from the existing literature. As a 
second step, we analyze projects according to their labor intensity. Firms might need to hire more workers in order to undertake additional projects or they might be able to secure jobs due to winning a project. An improvement in the employment numbers increases the chances of getting re-elected for the incumbent. Finally, we look at different size categories according to the contract value, as bigger projects might be more visible on average, even though many new smaller projects might attract the attention of voters even more.

For the first visibility category, we create a dummy variable that equals 1 for visible projects as classified by Chong et al. (2014) and Marx (2018) (see Section 2.1) according to the two-digit CPV division in TED. The categories classified as visible are indicated with an asterisk in Appendix Table A5.

The results in Table 4 suggest that the effects for visible contract awards (columns $1 \& 3$ ) are indeed larger than the effects for non-visible contract awards (columns $2 \&$ 4) for both the number and the aggregate value. However, the effects for non-visible awards are also statistically significant. Thus, incumbents do not seem to only rely on particularly visible projects. The last two columns of Table 4 test whether these differences are statistically significant by running interaction models that use the share of visible contracts in a given country and month. According to these results, the difference between visible and non-visible awards is only statistically significant for the aggregate value of contract awards but not for the number of awards.

For the second visibility category, to measure the labor intensity in each sector, we use OECD data on the gross value added (GVA) and employee compensations to calculate the share of employee compensation in GVA (OECD 2020). The two ingredient variables are available at the ISIC level such that we can match the CPVs of the TED data to the ISIC codes 17

\footnotetext{
${ }^{17}$ We only use the most recent available year such that labor intensity does not vary over time. For most countries, the latest year is 2018. Exceptions are the UK (2015) and Bulgaria, Croatia, Greece, and the Netherlands (2017). Note that the matching of CPV to ISIC codes is not the same as for the analyses in Figures 3 and A3, as sectors in the OECD data are broken down to lower levels of the ISIC classification for some countries.
} 
Table 4: Election effects by visibility of contract awards

\begin{tabular}{|c|c|c|c|c|c|c|}
\hline & \multirow{2}{*}{\multicolumn{2}{|c|}{$\begin{array}{l}(1) \\
\text { Number of contract awards }\end{array}$}} & \multirow{2}{*}{\multicolumn{2}{|c|}{$\begin{array}{c}(3) \\
\text { Aggr. value of contract awards }\end{array}$}} & \multirow{2}{*}{\multicolumn{2}{|c|}{$\begin{array}{l}(5) \quad(6) \\
\text { Interaction models }\end{array}$}} \\
\hline & & & & & & \\
\hline & Visible & Non-visible & Visible & Non-visible & Number & Aggr. value \\
\hline Election year & \multirow{3}{*}{$\begin{array}{c}0.1415^{* * *} \\
(0.0385)\end{array}$} & \multirow{3}{*}{$\begin{array}{c}0.1127^{* * *} \\
(0.0307)\end{array}$} & \multirow{3}{*}{$\begin{array}{c}0.1675^{* * *} \\
(0.0423)\end{array}$} & \multirow{3}{*}{$\begin{array}{l}0.0774^{*} \\
(0.0429)\end{array}$} & $\begin{array}{c}0.0666 \\
(0.0592)\end{array}$ & $\begin{array}{c}0.0277 \\
(0.0475)\end{array}$ \\
\hline$(\text { Elect. year })^{*}($ share visible $)$ & & & & & $\begin{array}{c}0.1492 \\
(0.1999)\end{array}$ & $\begin{array}{c}0.1772^{* * *} \\
(0.0834)\end{array}$ \\
\hline Share of visible contracts & & & & & $\begin{array}{c}0.0541 \\
(0.2202)\end{array}$ & $\begin{array}{c}0.5098^{* * *} \\
(0.1203)\end{array}$ \\
\hline Observations & 3,696 & 3,696 & 3,696 & 3,696 & 3,632 & 3,626 \\
\hline Country FE & yes & yes & yes & yes & yes & yes \\
\hline Month x Year FE & yes & yes & yes & yes & yes & yes \\
\hline Mean dep. Variable & 20.14 & 37.84 & 34206373 & 43404436 & 59 & 79105781 \\
\hline Pseudo LL & -14358 & -18933 & $-3.440 \mathrm{e}+10$ & $-2.600 e+10$ & -21709 & $-3.570 \mathrm{e}+10$ \\
\hline
\end{tabular}

Notes: PPML regressions. ${ }^{* * *} \mathrm{p}<0.01,{ }^{* *} \mathrm{p}<0.05,{ }^{*} \mathrm{p}<0.1$. Results correspond to Equation (1). The dependent variable only captures country aggregates for the respective category of contract awards: visible or non-visible. The election dummy captures parliamentary elections. Standard errors clustered at the country level.

Table 5 summarizes the results. Columns 1-4 again look at country aggregates for projects in the two categories separately (i.e., below vs. above median labor intensity), whereas columns 5 and 6 present the results from interaction models. For the separate regressions, the coefficient estimates for the election year dummy are fairly similar and there is no clear evidence suggesting that more labor-intensive projects are used more extensively before an election. The interaction models support this conclusion for the aggregate value of contract awards, whereas the evidence for the number of awards even speaks for a lower election cycle effect for projects with an above-median labor intensity. Thus, we reject the hypothesis that politicians use particularly labor-intensive public procurement projects before elections to signal a good shape of the economy under their government.

In a final step, we test whether project size matters for the identified election cycle effects. Table 6 therefore separately looks at below and above median-sized projects by studying country aggregates that only include observations from the respective category. For both the number of awards as well as the value of awards, the results suggest that the effect of elections is stronger for smaller projects. The difference 
Table 5: Election effects by labor intensity of contract awards

\begin{tabular}{|c|c|c|c|c|c|c|}
\hline & \multirow{2}{*}{\multicolumn{2}{|c|}{$\begin{array}{c}(1) \\
\text { Number of contract awards } \\
\end{array}$}} & \multirow{2}{*}{\multicolumn{2}{|c|}{$\begin{array}{c}(3) \\
\text { Aggr. value of contract awards }\end{array}$}} & \multirow{2}{*}{\multicolumn{2}{|c|}{$\begin{array}{l}(5) \quad(6) \\
\text { Interaction models }\end{array}$}} \\
\hline & & & & & & \\
\hline & Below median & Above median & Below median & Above median & Number & Aggr. value \\
\hline Election year & $\begin{array}{c}0.1158^{* * *} \\
(0.0340)\end{array}$ & $\begin{array}{c}0.1306^{* * *} \\
(0.0327)\end{array}$ & $\begin{array}{c}0.1359^{* * *} \\
(0.0494)\end{array}$ & $\begin{array}{c}0.1157^{* * *} \\
(0.0294)\end{array}$ & $\begin{array}{c}0.2326^{* * *} \\
(0.0549)\end{array}$ & $\begin{array}{l}-0.0205 \\
(0.0969)\end{array}$ \\
\hline (Elect. year $)^{*}($ share above median $)$ & & & & & $\begin{array}{c}-0.1943^{* *} \\
(0.0789)\end{array}$ & $\begin{array}{c}0.2310 \\
(0.1574)\end{array}$ \\
\hline Share above median labor intensity & & & & & $\begin{array}{c}0.2627 \\
(0.1806)\end{array}$ & $\begin{array}{l}-0.0290 \\
(0.2529)\end{array}$ \\
\hline Observations & 3,564 & 3,696 & 3,696 & 3,696 & 3,612 & 3,612 \\
\hline Control variables & yes & yes & yes & yes & yes & yes \\
\hline Country FE & yes & yes & yes & yes & yes & yes \\
\hline Month $\times$ Year FE & yes & yes & yes & yes & yes & yes \\
\hline Mean dep. variable & 23.7 & 34.04 & 37407638 & 39690139 & 59.61 & 79795406.38 \\
\hline Pseudo LL & -14733 & -18376 & $-3.030 \mathrm{e}+10$ & $-2.860 \mathrm{e}+10$ & -21579 & $-3.720 e+10$ \\
\hline
\end{tabular}

Notes: PPML regressions. ${ }^{* * *} \mathrm{p}<0.01,{ }^{* *} \mathrm{p}<0.05,{ }^{*} \mathrm{p}<0.1$. Results correspond to Equation (1). The dependent variable only captures country aggregates for the respective category of contract awards: projects with a labor intensity below or above the median. The election dummy captures parliamentary elections. Standard errors clustered at the country level.

in coefficient estimates is, however, very small for the value of contract awards ${ }^{18}$ From this perspective, the results speak for the interpretation that politicians rather initiate many smaller projects before elections to signal high competence but we cannot credibly test this using statistical procedures.

Table 6: Election effects by project size of contract awards

\begin{tabular}{|c|c|c|c|c|}
\hline & \multirow{2}{*}{\multicolumn{2}{|c|}{$\begin{array}{c}(1) \\
\text { Number of contract awards }\end{array}$}} & \multirow{2}{*}{\multicolumn{2}{|c|}{$\begin{array}{l}(3) \\
\text { Aggr. value of contract awards }\end{array}$}} \\
\hline & & & & \\
\hline & below median & above median & below median & above median \\
\hline Election year & $\begin{array}{c}0.1675 * * * \\
(0.0329)\end{array}$ & $\begin{array}{c}0.1255^{* * *} \\
(0.0318)\end{array}$ & $\begin{array}{c}0.1335 * * * \\
(0.0353)\end{array}$ & $\begin{array}{c}0.1248 * * * \\
(0.0349)\end{array}$ \\
\hline Observations & 3,696 & 3,696 & 3,696 & 3,696 \\
\hline Control variables & yes & yes & yes & yes \\
\hline Country FE & yes & yes & yes & yes \\
\hline Month $\times$ Year FE & yes & yes & yes & yes \\
\hline Mean dependent variable & 25.39 & 25.30 & 3468694 & 73710363 \\
\hline Pseudo LL & -17605 & -14917 & $-1.230 \mathrm{e}+09$ & $-3.880 e+10$ \\
\hline
\end{tabular}

Notes: PPML regressions. ${ }^{* * *} \mathrm{p}<0.01,{ }^{* *} \mathrm{p}<0.05,{ }^{*} \mathrm{p}<0.1$. Results correspond to Equation (1). The dependent variable only captures country aggregates for the respective category of contract awards: projects with a project size below or a above the median. The election dummy captures parliamentary elections. Standard errors clustered at the country level.

\footnotetext{
${ }^{18}$ We abstain from estimating interaction models in this context as the models would be highly endogenous due to reverse causality.
} 
To summarize this section, incumbents seem to make use of particularly visible projects (e.g., projects in education, health, construction, or recreational services) and initiate many smaller projects rather than larger ones before an election to signal high competence and good performance to voters.

\section{Conclusion}

Our analysis provides additional evidence that specific spending instruments with well-defined target groups have a particular appeal to policy-makers facing the next election. Our results show significant increases in the posting of calls for tenders and the awarding of public procurement contracts prior to national parliamentary elections. The robust result for awards is in line with our theoretical expectations. Within the procurement cycle, the award decision has two implications that explain its usefulness in election campaigns. First, the award identifies the winning firm and pleases all its stakeholders. With the award, policy-makers can thus favor additional target groups beyond those who will use the public good provided. Second, the contract award is the point of no return for the spending decision and should, therefore, also appeal to a forward-looking type of voter who distrusts non-binding political spending announcements.

Moreover, we are able to show that the election cycle is more pronounced for some sub-categories. We observe strong election year effects for certain sectors, especially education. A higher aggregate value of public procurement contracts is awarded prior to an election for visible projects as defined by the existing literature 19 We do not observe a systematically different pattern for services, supplies, or works contracts and reject the hypothesis that politicians use particularly labor-intensive public procurement projects before elections.

\footnotetext{
${ }^{19}$ This includes projects from categories such as public utilities, construction work, recreational services, or repair and maintenance services.
} 
Our study is based on procurement data from the European TED database. This has the strength that our insights are based on procurement processes all over the EU. The downside is that our conclusions cannot be directly transferred to smaller procurement projects that are below the size thresholds of the TED data and therefore do not have to be posted on TED. Our heterogeneity results suggest, however, that election cycle effects in public procurement could even be somewhat stronger for smaller projects. Another caveat is that the coverage of project completions is more limited compared to notices and awards so that our weaker findings for completions must be interpreted with some caution.

Given the strong theoretical case for a likely election pattern in public procurement, the literature is clearly underdeveloped. For example, studies on election cycles in public procurement for local jurisdictions are still largely missing (with the exception of Chong et al. (2014) for French municipalities). Given the enormous importance of the local level for visible infrastructure and public services so close to citizens, this is a serious white spot. Our study focuses on national authorities and we cannot be sure on our findings' relevance for sub-national or local jurisdictions. We would expect a broader validity as, for example, a meta-analysis by Philips (2016) suggests that political budget cycles, if anything, tend to be stronger at the local level compared to the national government level. However, more research is needed to confirm this for procurement. 


\section{References}

Alesina, A. and G. Tabellini (1990). A positive theory of fiscal deficits and government debt. The Review of Economic Studies 57(3), 403-414.

Armingeon, K., V. Wenger, F. Wiedemeier, C. Isler, L. Knöpfel, D. Weisstanner, and S. Engler (2020). Comparative Political Data Set 1960-2018. Bern: Institute of Political Science, University of Berne.

Bove, V., G. Efthyvoulou, and A. Navas (2017). Political Cycles in Public Expenditure: Butter vs Guns. Journal of Comparative Economics 45(3), 582 - 604.

Castellani, L., F. Decarolis, and G. Rovigatti (2018). Procurement Centralization in the EU: the Case of Italy. CEPR Discussion Paper Series 12567.

Chong, E., M. Klien, and J. Moore (2014). Elections and project delivery in public work procurement: A red ribbon effect? EPPP Discussion Paper No. 11.

De Haan, J. and J. Klomp (2013a). Conditional Election and Partisan Cycles in Government Support to the Agricultural Sector: An Empirical Analysis. American Journal of Agricultural Economics 95(4), 793-818.

De Haan, J. and J. Klomp (2013b). Conditional Political Budget Cycles: A Review of Recent Evidence. Public Choice 157, 387-410.

Enkelmann, S. and M. Leibrecht (2013). Political expenditure cycles and election outcomes: Evidence from disaggregation of public expenditures by economic functions. Economics Letters 121(1), 128 - 132.

European Commission (2020a). Public procurement. https://ec.europa.eu/ info/policies/public-procurement_en [Accessed: 2020-10-31].

European Commission (2020b). Thresholds. https://ec.europa.eu/growth/ single-market/public-procurement/rules-implementation/thresholds_ en [Accessed: 2020-10-31].

Foremny, D., R. Freier, M.-D. Moessinger, and M. Yeter (2018). Overlapping political budget cycles. Public Choice 177, $1-27$.

Franzese, R. J. (2002). Electoral and partisan cycles in economic policies and outcomes. Annual Review of Political Science 5(1), 369-421.

Fuest, C., A. Peichl, and S. Siegloch (2018). Do Higher Corporate Taxes Reduce Wages? Micro Evidence from Germany. American Economic Review 108(2), $393-418$.

Geys, B. (2013). Election Cycles in MPs' outside Interests? The UK House of Commons, 2005-2010. Political Studies 61(2), 462-472.

Hibbs, D. (1977). Political parties and macroeconomic policy. American Political Science Review 71(4), 1467-1487. 
Kline, P. and A. Santos (2012). A Score Based Approach to Wild Bootstrap Inference. Journal of Econometric Methods 1(1), 23 - 41.

Marx, B. (2018). Elections as Incentives: Project Completion and Visibility in African Politics. Mimeo.

Nordhaus, W. D. (1975). The political business cycle. The Review of Economic Studies 42(2), 169-190.

OECD (2020). 6A. Value added and its components by activity, ISIC rev4. https: // stats.oecd.org/Index. aspx?DataSetCode=SNA_TABLE6A [Accessed: 2020-1010].

Philips, A. Q. (2016). Seeing the forest through the trees: a meta-analysis of political budget cycles. Public Choice 168(3), 313-341.

Rogoff, K. (1990). Equilibrium political budget cycles. The American Economic Review 80, 21-36.

Rogoff, K. and A. Sibert (1988). Elections and macroeconomic policy cycles. The Review of Economic Studies 55(1), 1-16.

Santos Silva, J. and S. Tenreyro (2006). The Log of Gravity. The Review of Economics and Statistics 88(4), 641-658.

Schmidheiny, K. and S. Siegloch (2019). On event study designs and distributed-lag models: Equivalence, generalization and practical implications. CESifo Working Paper 7481.

Schuknecht, L. (2000). Fiscal policy cycles and public expenditure in developing countries. Public Choice 102, 113-128.

Skuhrovec, J. (2017). The Elephant in the room - Government spending outside public procurement. https://medium.com/datlab/ the-elephant-in-the-room-acb12a0908da, accessed Nov 28, 2018.

Todtenhaupt, M., J. Voget, L. P. Feld, M. Ruf, and U. Schreiber (2020). Taxing away M\&A: Capital gains taxation and acquisition activity. European Economic Review 128, 103505.

Tufte, E. (1978). Political control of the economy. Princeton University Press.

Vergne, C. (2009). Democracy, elections and allocation of public expenditures in developing countries. European Journal of Political Economy 25(1), 63 - 77. 


\section{Appendix}

Table A1: Summary statistics

\begin{tabular}{lllllll}
\hline Variable & Obs & Mean & Std. dev. & Min & Max & Source \\
\hline Number of contract notices & 3,696 & 60.44 & 66.87 & 0 & 621 & TED \\
Aggregate value of contract notices & 3,696 & $9.640 \mathrm{e}+07$ & $1.300 \mathrm{e}+08$ & 0 & $1.010 \mathrm{e}+09$ & TED \\
Number of contract awards & 3,696 & 57.80763 & 66.08512 & 0 & 896 & TED \\
Aggregate value of contract awards & 3,696 & $7.72 \mathrm{e}+07$ & $9.60 \mathrm{e}+07$ & 0 & $1.18 \mathrm{e}+09$ & TED \\
Number of contract completions & 3,696 & 9.332522 & 19.65615 & 0 & 278 & TED \\
Aggregate value of contract completions & 3,696 & $1.22 \mathrm{E}+07$ & $2.95 \mathrm{e}+07$ & 0 & $4.53 \mathrm{e}+08$ & TED \\
Parliamentary election year & 3,696 & 0.247 & 0.431 & 0 & 1 & International IDEA \\
Presidential election year & 3,696 & 0.0920 & 0.289 & 0 & 1 & International IDEA \\
GDP growth rate & 3,696 & 2.913 & 5.644 & -22.91 & 34.91 & Eurostat \\
Unemployment rate & 3,696 & 9.151 & 4.594 & 2.200 & 27.50 & Eurostat \\
Ln population & 3,696 & 15.87 & 1.408 & 12.92 & 18.23 & Eurostat \\
Government expenditure / GDP & 3,696 & 45.60 & 6.536 & 25.30 & 65.10 & Eurostat \\
Share population under 15 & 3,696 & 15.76 & 1.710 & 13.10 & 21.90 & Eurostat \\
Share population over 64 & 3,696 & 17.45 & 2.378 & 10.80 & 22.60 & Eurostat \\
Left seat share in parliament & 3,696 & 33.54 & 35.66 & 0 & 100 & CPDS \\
\hline
\end{tabular}

Table A2: Baseline regression results - Quarterly aggregation

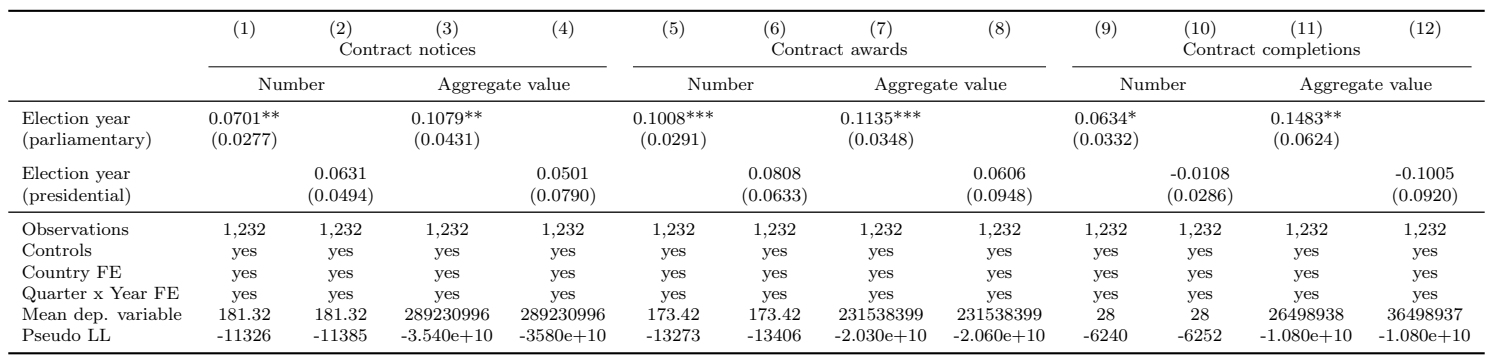

Notes: PPML regressions. ${ }^{* * *} \mathrm{p}<0.01,{ }^{* *} \mathrm{p}<0.05,{ }^{*} \mathrm{p}<0.1$. Results correspond to Equation (1) but are based on a quarterly aggregation of the project data to reduce the issue of low numbers for project completions per month. Standard errors clustered at the country level. 
Table A3: Effects of different years in the election cycle

\begin{tabular}{|c|c|c|c|c|c|c|c|c|}
\hline \multirow[t]{2}{*}{ Panel A } & (1) & & & $(4)$ & (5) & (6) & $(7)$ & $(8)$ \\
\hline & \multicolumn{4}{|c|}{ Number of contract notices } & \multicolumn{4}{|c|}{ Aggregate value of contract notices } \\
\hline Months before election & $25-36$ & 13-24 & 0-12 & 0-12 (after) & 25-36 & 13-24 & 0-12 & 0-12 (after) \\
\hline Election cycle & $\begin{array}{l}-0.0478 \\
(0.0304)\end{array}$ & $\begin{array}{c}0.0090 \\
(0.0323)\end{array}$ & $\begin{array}{c}0.0806^{* * *} \\
(0.0290)\end{array}$ & $\begin{array}{l}-0.0247 \\
(0.0248)\end{array}$ & $\begin{array}{l}-0.0053 \\
(0.0348)\end{array}$ & $\begin{array}{c}0.0661 \\
(0.0484)\end{array}$ & $\begin{array}{c}0.1259^{* * *} \\
(0.0440)\end{array}$ & $\begin{array}{c}-0.1273^{* * *} \\
(0.0368)\end{array}$ \\
\hline \multirow[t]{2}{*}{ Panel B } & (1) & (2) & (3) & $(4)$ & (5) & (6) & $(7)$ & $(8)$ \\
\hline & \multicolumn{4}{|c|}{ Number of contract awards } & \multicolumn{4}{|c|}{ Aggregate value of contract awards } \\
\hline Election cycle & $\begin{array}{c}-0.0381^{*} \\
(0.0228)\end{array}$ & $\begin{array}{c}0.0423^{* *} \\
(0.0175)\end{array}$ & $\begin{array}{c}0.1235^{* * *} \\
(0.0314)\end{array}$ & $\begin{array}{c}-0.0556^{* * *} \\
(0.0192)\end{array}$ & $\begin{array}{c}-0.0443^{* *} \\
(0.0225)\end{array}$ & $\begin{array}{c}0.0596 * \\
(0.0306)\end{array}$ & $\begin{array}{c}0.1258^{* * *} \\
(0.0343)\end{array}$ & $\begin{array}{c}-0.0553^{*} \\
(0.0310)\end{array}$ \\
\hline Observations & 3,696 & 3,696 & 3,696 & 3,696 & 3,696 & 3,696 & 3,696 & 3,696 \\
\hline Control variables & yes & yes & yes & yes & yes & yes & yes & yes \\
\hline Country FE & yes & yes & yes & yes & yes & yes & yes & yes \\
\hline Month $\times$ Year FE & yes & yes & yes & yes & yes & yes & yes & yes \\
\hline
\end{tabular}

Notes: PPML regressions. ${ }^{* * *} \mathrm{p}<0.01,{ }^{* *} \mathrm{p}<0.05,{ }^{*} \mathrm{p}<0.1$. Results correspond to Equation (1) with the difference that the election dummy represents a different year in each regression. The election dummy captures parliamentary elections. Standard errors clustered at the country level.

Table A4: Contract awards by ISIC section for national authorities

\begin{tabular}{llll}
\hline Section & Aggregate value $^{1}$ & Number & ISIC description \\
\hline $\mathrm{A}$ & 2270.52 & 3084 & Agriculture. forestry and fishing \\
$\mathrm{B}$ & 14215.3 & 6848 & Mining and quarrying \\
$\mathrm{C}$ & 87145.64 & 84189 & Manufacturing \\
$\mathrm{D} / \mathrm{E}$ & 11982.38 & 12714 & Electricity, gas, steam and air conditioning supply, Water supply; \\
& & & sewerage, waste management and remediation activities \\
$\mathrm{F}$ & 82578.81 & 19659 & Construction \\
$\mathrm{H}$ & 9074.6 & 6056 & Transportation and storage \\
$\mathrm{I}$ & 3619.97 & 3103 & Accommodation and food service activities \\
$\mathrm{J}$ & 35990.99 & 27435 & Information and communication \\
$\mathrm{K}$ & 3564.8 & 2858 & Financial and insurance activities \\
$\mathrm{L}$ & 761.1 & 579 & Real estate activities \\
$\mathrm{M}$ & 36966.87 & 43743 & Professional, scientific and technical activities \\
$\mathrm{O}$ & 3199.34 & 1762 & Public administration and defence; compulsory social security \\
$\mathrm{P}$ & 5120.02 & 5911 & Education \\
$\mathrm{Q}$ & 6213.02 & 5349 & Human health and social work activities \\
$\mathrm{R}$ & 654.42 & 1136 & Arts, entertainment and recreation \\
$\mathrm{S} / \mathrm{U}$ & 2040.46 & 1868 & Other service activities, Activities of extraterritorial organizations and bodies \\
$\mathrm{V}$ & 16914.39 & 13637 & Repair and maintenance services \\
$\mathrm{W}$ & 344.33 & 299 & Installation services (except software) \\
$\mathrm{X}$ & 5998.33 & 3924 & Postal and telecommunication services \\
\hline
\end{tabular}

Notes: ${ }^{1}$ Aggregate value of contract awards in million euros. Source: own calculations based on the TED dataset. 
Table A5: Correspondence table for CPV and ISIC codes

\begin{tabular}{|c|c|c|c|}
\hline CPV label & CPV & ISIC & ISIC rev. 4 label \\
\hline Agricultural, farming, fishing, forestry and related products & 3 & A & Agriculture, forestry and fishing \\
\hline Agricultural, forestry, horticultural, aquacultural and apicultural services & 77 & A & Agriculture, forestry and fishing \\
\hline Petroleum products, fuel, electricity and other sources of energy & 9 & B & Mining and quarrying \\
\hline Mining, basic metals and related products & 14 & B & Mining and quarrying \\
\hline Services related to the oil and gas industry & 76 & B & Mining and quarrying \\
\hline Food, beverages, tobacco and related products & 15 & $\mathrm{C}$ & Manufacturing \\
\hline Agricultural machinery & 16 & $\mathrm{C}$ & Manufacturing \\
\hline Clothing, footwear, luggage articles and accessories & 18 & $\mathrm{C}$ & Manufacturing \\
\hline Leather and textile fabrics, plastic and rubber materials & 19 & $\mathrm{C}$ & Manufacturing \\
\hline Printed matter and related products & 22 & $\mathrm{C}$ & Manufacturing \\
\hline $\begin{array}{ll}\text { Chemical products } & \text { Che }\end{array}$ & 24 & $\mathrm{C}$ & Manufacturing \\
\hline Office and computing machinery, equipment and supplies except furniture and software packages & 30 & $\mathrm{C}$ & Manufacturing \\
\hline Electrical machinery, apparatus, equipment and consumables; lighting & 31 & $\mathrm{C}$ & Manufacturing \\
\hline Medical equipments, pharmaceuticals and personal care products & 33 & $\mathrm{C}$ & Manufacturing \\
\hline Transport equipment and auxiliary products to transportation & 34 & $\mathrm{C}$ & Manufacturing \\
\hline Security, fire-fighting, police and defence equipment & 35 & $\mathrm{C}$ & Manufacturing \\
\hline Musical instruments, sport goods, games, toys, handicraft, art materials and accessories & $37^{*}$ & $\mathrm{C}$ & Manufacturing \\
\hline Laboratory, optical and precision equipments (excl. glasses) & 38 & $\mathrm{C}$ & Manufacturing \\
\hline Furniture (incl. office furniture), furnishings, domestic appliances (excl. lighting) and cleaning products & 39 & $\mathrm{C}$ & Manufacturing \\
\hline Industrial machinery & 42 & $\mathrm{C}$ & Manufacturing \\
\hline Machinery for mining, quarrying, construction equipment & 43 & $\mathrm{C}$ & Manufacturing \\
\hline Construction structures and materials; auxiliary products to construction (except electric apparatus) & 44 & $\mathrm{C}$ & Manufacturing \\
\hline Collected and purified water & $41^{*}$ & $\mathrm{D} / \mathrm{E}$ & Electricity, gas, steam and air conditioning supply, Water \\
\hline Public utilities & $65^{*}$ & $\mathrm{D} / \mathrm{E}$ & supply; sewerage, waste management and remediation \\
\hline Sewage, refuse, cleaning and environmental services & $90^{*}$ & $\mathrm{D} / \mathrm{E}$ & activities \\
\hline Construction work & $45^{*}$ & $\mathrm{~F}$ & Construction \\
\hline Transport services (excl. Waste transport) & 60 & $\mathrm{H}$ & Transportation and storage \\
\hline Supporting and auxiliary transport services; travel agencies services & 63 & $\mathrm{H}$ & Transportation and storage \\
\hline Hotel, restaurant and retail trade services & 55 & I & Accommodation and food service activities \\
\hline Radio, television, communication, telecommunication and related equipment & 32 & $\mathrm{~J}$ & Information and communication \\
\hline Software package and information systems & 48 & $\mathrm{~J}$ & Information and communication \\
\hline IT services: consulting, software development, Internet and support & 72 & $\mathrm{~J}$ & Information and communication \\
\hline Financial and insurance services & 66 & $\mathrm{~K}$ & Financial and insurance activities \\
\hline Real estate services & 70 & $\mathrm{~L}$ & Real estate activities \\
\hline Architectural, construction, engineering and inspection services & $71^{*}$ & M & Professional, scientific and technical activities \\
\hline Research and development services and related consultancy services & 73 & $\mathrm{M}$ & Professional, scientific and technical activities \\
\hline Business services: law, marketing, consulting, recruitment, printing and security & 79 & M & Professional, scientific and technical activities \\
\hline Administration, defence and social security services & 75 & $\mathrm{O}$ & Public administration and defence; compulsory social security \\
\hline Education and training services & $80^{*}$ & $\mathrm{P}$ & Education \\
\hline Health and social work services & $85^{*}$ & $\mathrm{Q}$ & Human health and social work activities \\
\hline Recreational, cultural and sporting services & $92^{*}$ & $\mathrm{R}$ & Arts, entertainment and recreation \\
\hline Other community, social and personal services & $98^{*}$ & $\mathrm{~S} / \mathrm{U}$ & Other service activities, Activities of extraterritorial bodies \\
\hline Repair and maintenance services & $50^{*}$ & $\mathrm{~V}$ & Repair and maintenance services \\
\hline Installation services (except software) & $51^{*}$ & $\mathrm{~W}$ & Installation services (except software) \\
\hline Postal and telecommunications services & $64^{*}$ & $\mathrm{X}$ & Postal and telecommunication services \\
\hline
\end{tabular}

Notes: This table documents the manual matching of the CPV division codes in the TED data with the ISIC rev. 4 section codes. 
Figure A1: Descriptive evidence

(a) Number of contract notices

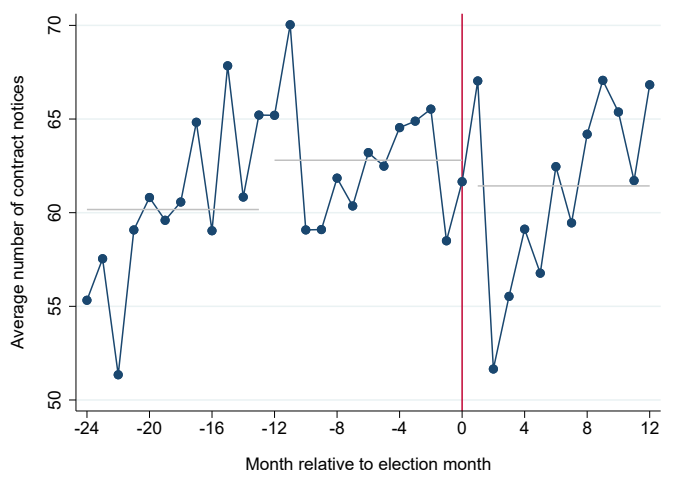

(c) Number of contract awards

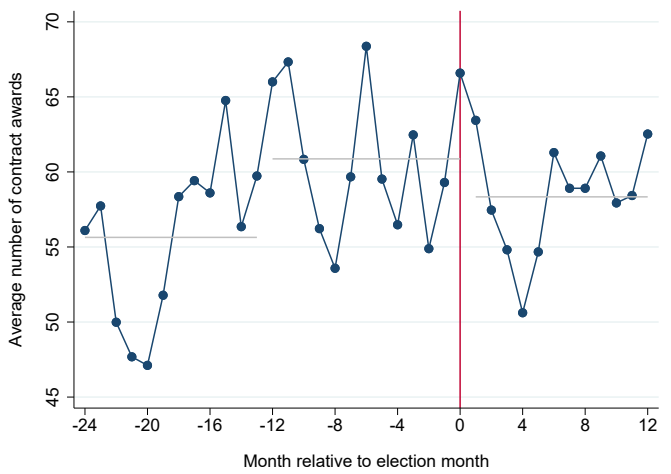

(e) Number of contract completions

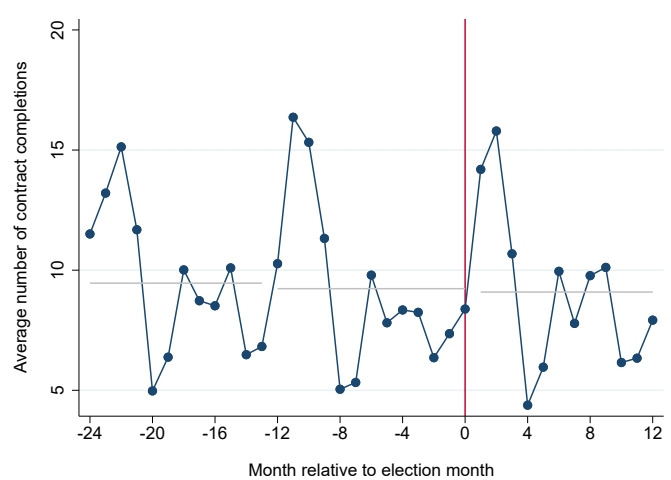

(b) Aggregate value of contract notices

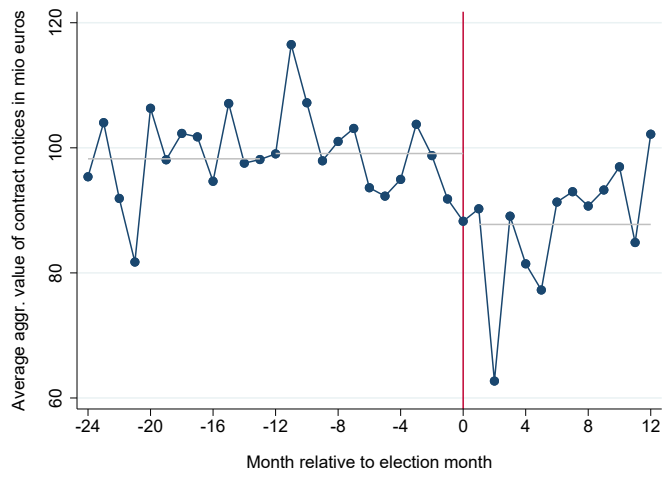

(d) Aggregate value of contract awards

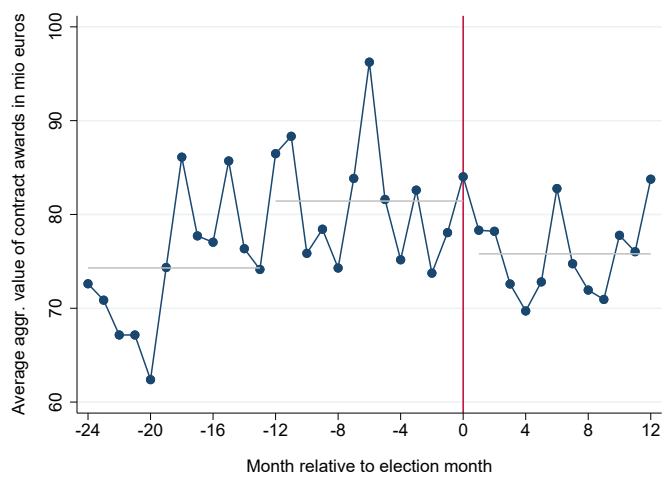

(f) Aggr. value of contract completions

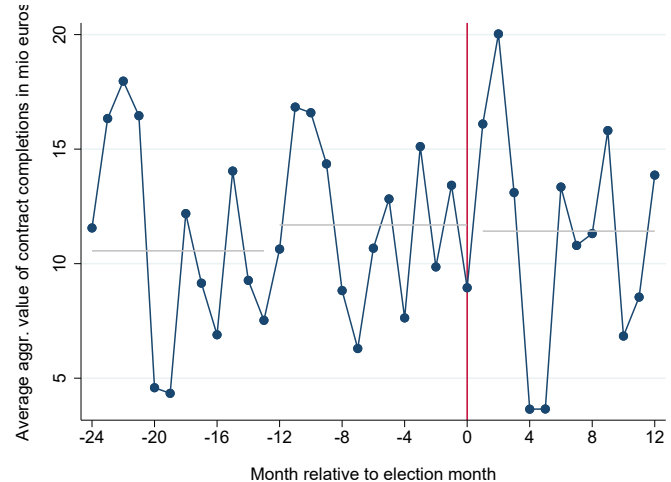

Notes: The figures plot monthly averages of the number and the value of contract notices, contract awards, and contract completions around parliamentary elections. Gray horizontal lines indicate twelve months averages. 
Figure A2: Event study analysis as linear model

(a) Number of contract notices

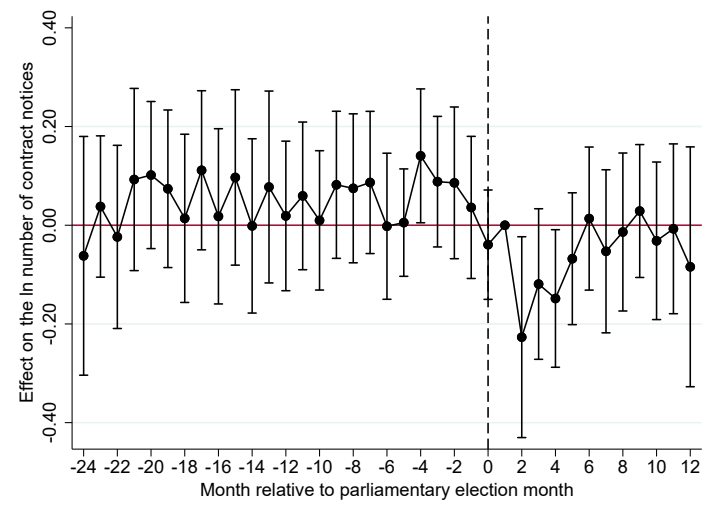

(c) Number of contract awards

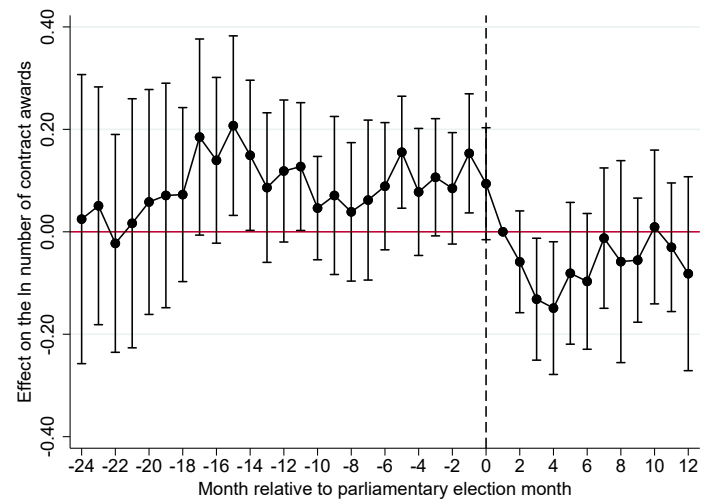

(b) Aggregate value of contract notices

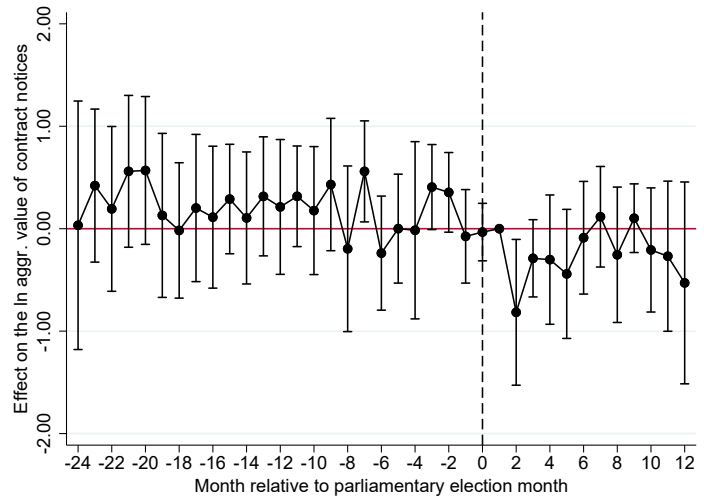

(d) Aggregate value of contract awards

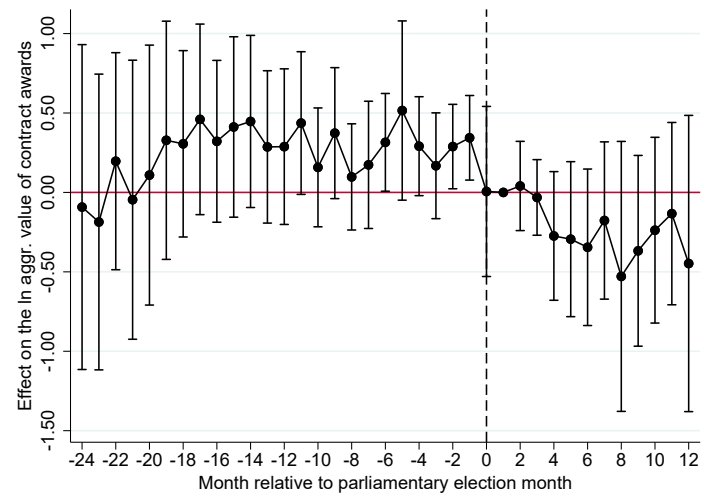

Notes: Coefficient estimates and $95 \%$ confidence intervals for the event study model in Equation (2 in the linear version. The dependent variable is defined as the natural logarithm, that is $\ln ($ variable +1$)$. Standard errors clustered at the country level.

Figure A3: Election effects on the value of contract awards by ISIC sector codes

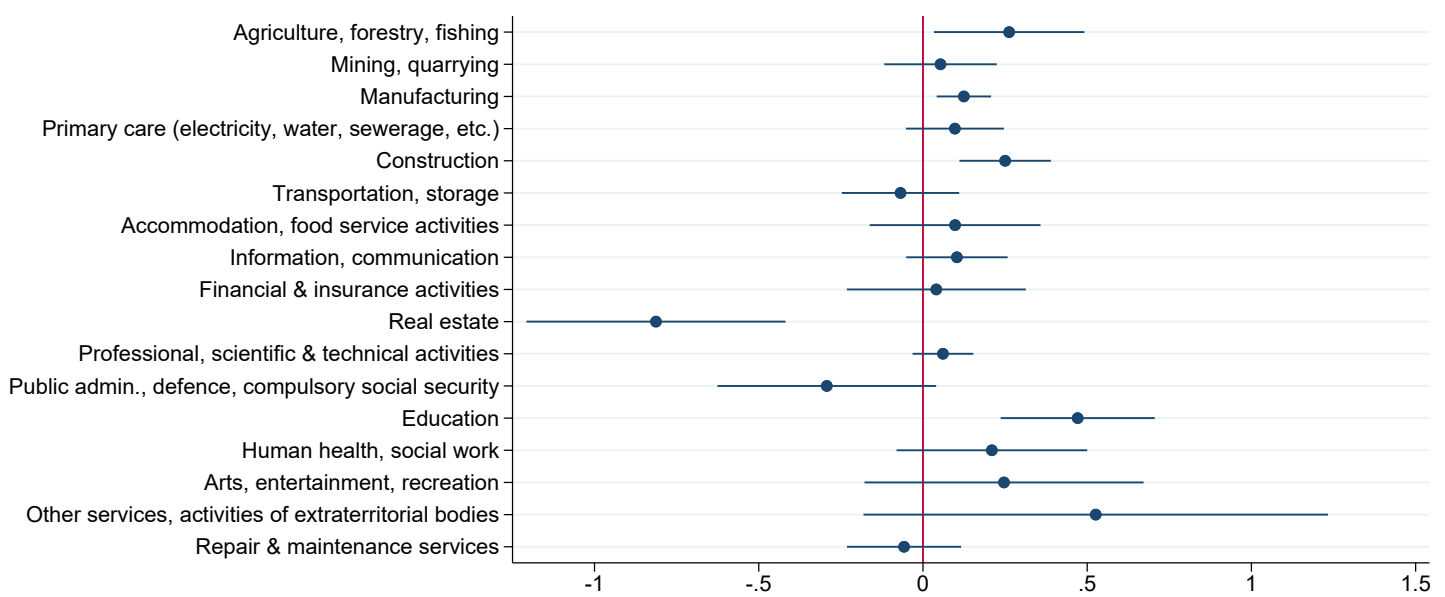

Notes: Coefficient estimates and $95 \%$ confidence intervals for the parliamentary election year dummy. Separate regressions. The dependent variable only captures country aggregates for the respective category of contract awards as defined by the labels. Results correspond to Equation (1). Standard errors clustered at the country level. 
Download ZEW Discussion Papers from our ftp server:

http://ftp.zew.de/pub/zew-docs/dp/

or see:

https://www.ssrn.com/link/ZEW-Ctr-Euro-Econ-Research.html

https://ideas.repec.org/s/zbw/zewdip.html

$$
\text { // }
$$

IMPRINT

ZEW - Leibniz-Zentrum für Europäische Wirtschaftsforschung GmbH Mannheim

ZEW - Leibniz Centre for European

Economic Research

L 7,1 68161 Mannheim · Germany

Phone +49621 1235-01

info@zew.de·zew.de

Discussion Papers are intended to make results of ZEW research promptly available to other economists in order to encourage discussion and suggestions for revisions. The authors are solely responsible for the contents which do not necessarily represent the opinion of the ZEW. 